\title{
Implications of domestic dogs in the epidemiology of Rickettsia parkeri strain Atlantic rainforest and Rangelia vitalii in Southeastern Brazil
}

\author{
Implicações dos cães domésticos na epidemiologia da Rickettsia parkeri \\ cepa Mata Atlântica e da Rangelia vitalii no Sudeste do Brasil
}

Gislene Fátima da Silva Rocha Fournier ${ }^{1,2}$; Adriano Pinter ${ }^{3}$; Sebastian Muñoz-Leal2;

Marcelo Bahia Labruna²; Marcos Gomes Lopes²; Thiago Fernandes Martins²; Luciana Colácio ${ }^{4}$; Cayo Rodrigo Santos Môra5; Jonas Moraes-Filho6; Ricardo Augusto Dias ${ }^{2 *}$ (1)

${ }^{1}$ Centro de Inovação, Tecnologia e Educação - CITÉ, São José dos Campos, SP, Brasil

2 Departamento de Medicina Veterinária Preventiva e Saúde Animal, Faculdade de Medicina Veterinária e Zootecnia, Universidade de São Paulo - USP, São Paulo, SP, Brasil

${ }^{3}$ Superintendência de Controle de Endemias de São Paulo, São Paulo, SP, Brasil

${ }^{4}$ COLLIS Laboratório de Análise Clínica, Caraguatatuba, SP, Brasil

${ }^{5}$ Parque Estadual Serra do Mar - Núcleo Caraguatatuba, Caraguatatuba, São Paulo, SP, Brasil

${ }^{6}$ Universidade Santo Amaro - UNISA, São Paulo, SP, Brasil.

How to cite: Fournier GFSR, Pinter A, Muñoz-Leal S, Labruna MB, Lopes MG, Martins TF, Colácio L, Môra CRS, Moraes-Filho J, Dias RA. Implications of domestic dogs in the epidemiology of Rickettsia parkeri strain Atlantic rainforest and Rangelia vitalii in Southeastern Brazil. Braz J Vet Parasitol 2020; 29(1): e022419. https://doi.org/10.1590/S1984-29612020003.

\begin{abstract}
This study aimed to evaluate the occurrence of diseases transmitted by Amblyomma ovale in 61 dogs monitored for three years through collections of ticks and blood, interviews, telemetry and camera traps in three areas of Serra do Mar State Park, Brazil. Blood samples were used to investigate infection by Rangelia vitalii by real-time TaqMan PCR and Rickettsia parkeri by IIFA. The collected ticks were submitted to conventional PCR to investigate the presence of $R$. parkeri. These data were compared with the monitoring results and interviews with the owners. Dogs considered as companion presented a risk of infection by $R$. parkeri strain Mata Atlantica 5.4 times higher than those not considered as companion $(p=0.009)$. Dogs that had at least one $A$. ovale collected during the campaigns had a 10 times higher risk of infection by $R$. parkeri strain Mata Atlantica than those who did not $(p=0.009)$. One dog positive for $R$. vitalii by real-time TaqMan PCR was parasitized by A. ovale frequently during monitoring. Sequenced ompaA - positive DNA samples had $100 \%$ identity of R. parkeri strain Mata Atlantica clone As106. From the findings, it is urgent to control domestic dogs around rainforests to reduce zoonoses transmission.
\end{abstract}

Keywords: Dog, Rickettsia parkeri, Rangelia vitalii, Atlantic forest, Brazil.

\section{Resumo}

A ocorrência de doenças transmitidas por Amblyomma ovale em 61 cães monitorados por três anos através de coletas de carrapatos, sangue, entrevistas, telemetria e armadilhas fotográficas foi avaliada em três áreas do Parque Estadual da Serra do Mar - SP. Amostras de sangue foram utilizadas para investigação de Rangelia vitalii através de PCR TaqMan em tempo real e Rickettsia parkeri através da RIFI. Carrapatos coletados foram submetidos à PCR convencional para investigação de $R$. parkeri. Estes dados foram comparados considerando os resultados do

Received December 9, 2019. Accepted December 16, 2019.

Financial support: This stydy was financed in part by the Coordenação de Aperfeiçoamento de Pessoal de Nível Superior - Brasil (CAPES) - Finance support code 001 .

*Corresponding author: Ricardo Augusto Dias. E-mail: ricardodias@usp.br 
monitoramento e entrevistas. Cães de companhia apresentaram risco de infecção pela $R$. parkeri cepa Mata Atlântica 5,4 vezes maior que os não considerados como de companhia $(p=0,009)$. Cães que tiveram pelo menos um $A$. ovale coletado apresentaram risco de infecção por $R$. parkeri cepa Mata Atlântica 10 vezes maior do que aqueles que não tiveram $(p=0,009)$. Um cão positivo para R. vitalii através de PCR TaqMan em tempo real foi parasitado por $A$. ovale durante 0 monitoramento. Amostras positivas para o gene ompaA possuíam $100 \%$ de identidade do clone As106 de R. parkeri cepa de Mata Atlântica. Assim, é urgente o controle de cães na Mata Atlântica para redução dos riscos de zoonoses.

Palavras-chave: Cão, Rickettsia parkeri, Rangelia vitalii, Mata Atlântica, Brasil.

\section{Introduction}

Domestic dogs (Canis lupus familiaris) are common companions of humans during outdoor activities, playing different roles such as hunters, shepherds, watchers or companion animals (Chapman et al., 2006; Udell \& Wynne, 2008). In human dwellings located within or near forests, companion dogs often follow their owners in the natural environments they go to (Frigeri et al., 2014). However, the introduction of domestic dogs into wild ecosystems may cause deleterious effects. The invasion of dogs in forest environments represents a threat to wildlife, which has been published in recent decades (Martinez et al., 2013; Frigeri et al., 2014; Doherty et al., 2017). Particularly in Brazil, studies performed in the Atlantic rainforests also suggest that not only dogs invade these ecosystems (Srbek-Araujo \& Chiarello, 2008; Torres \& Prado, 2010), but also represent a threat to wild vertebrates (Lessa et al., 2016).

Brazil is home to an estimated 52 million owned dogs, according to the most recent government statistics, more than anywhere in Latin America (IBGE, 2017). However, it is still unknown what is the estimate of dogs that live around forested areas of Atlantic Forest. If considered that each family in the rural have at least one associated dog (Fiorello et al., 2006; Paschoal et al., 2012), the potential for forest dog invasion can be devastating. The domestic dog is considered a serious hazard for the native fauna, not only because of its impact on predators but mainly due to its role as potential vectors of pathogens (Fiorello et al., 2006; Paschoal et al., 2012).

In the Atlantic rainforests of Southeastern Brazil, adults of two tick species, namely Amblyomma aureolatum and Amblyomma ovale, parasitize wild canids such as Cerdocyon thous and Lycalopex vetulus, and are implied in the transmission of pathogenic Rangelia vitalli and Rickettsia spp. (Labruna et al., 2001, 2011; Saito et al., 2008; Soares et al., 2014; Malheiros et al., 2016; Soares et al., 2018; Mongruel et al., 2018). Meanwhile, dogs entering Atlantic rainforest areas can also host adults of both tick species (Sabatini et al., 2010; Ogrzewalska et al., 2012; Ferreira et al., 2013; Londoño et al., 2014; Gottlieb et al., 2016), yet in particular, adults of A. ovale (Martins et al., 2012; Londoño et al., 2014; Krawczak et al., 2016).

The epidemiological implications of domestic dogs entering Atlantic rainforest remnants is highly dependent not only on the role that these animals play in the life cycles of parasites and pathogenic agents but also on the environment in which they lives (Ogrzewalska et al., 2012; Saraiva et al., 2014).

In 2010, a clinical condition similar to Rickettsia parkeri rickettsiosis, was described in humans from the São Paulo State, Brazil, (Spolidorio et al., 2010). Based on a multilocus analysis, the phylogenetic position of this agent has been recently reassessed, re-naming it as R. parkeri strain Atlantic rainforest (Nieri-Bastos et al. 2018). Currently, A. ovale is considered the main vector of $R$. parkeri strain Atlantic rainforest in the São Paulo State (Szabó et al., 2013; Krawczak et al., 2016). Remarkably, dogs are closely linked to human cases of rickettsiosis registered in this Brazilian State, since they bring infected ticks from the environment into their owners' dwellings (Ogrzewalska et al., 2012).

Rangeliosis is another neglected disease described in several areas of Southeastern and Southern Brazil (Gottlieb et al., 2016; Soares et al., 2018). The etiological agent of the 
disease corresponds to the protozoan Rangelia vitalii, which still lacks a proper taxonomic position, yet it is currently classified within the Babesidae family of hemoprotozoa because of genetic and morphological affinities (Soares et al., 2018). Few studies on the presence of this parasite in canine populations and its prevalence have been published (Soares et al., 2012; Moreira et al., 2013; Gottlieb et al., 2016). Still unclear, rangeliosis might be widely distributed in the Southeastern and Southern regions of Brazil, and its clinical signs confused with Babesia vogeli infections (Carini, 1908; Pestana, 1910).

Dogs may share pathogens with wildlife, especially if neglected by their owners. The understanding the epidemiological role of these animals in areas surrounding an Atlantic Rainforest patch is a turning point for the development of zoonosis control programs.

The aim of this study was to evaluate the role of domestic dogs as carriers of $A$. ovale and tick-borne pathogens associated with $R$. parkeri and $R$. vitalii within Atlantic rainforest remnants from the Caraguatatuba municipality, state of São Paulo, Brazil. To achieve that, blood samples and ticks were collected from dogs and these samples were analyzed through molecular and serological techniques. In addition, to evaluate the use of the rainforest patches by domestic dogs, telemetric and photographic records obtained along three years in three different areas located in the surroundings of the Serra do Mar State Park were made.

\section{Material and Methods}

\section{Study area}

The dogs were chosen in Caraguatatuba, a city located next to Atlantic rainforest remnants in the São Paulo State, which the urban occupation sometimes extends illegally into preserved forest patches (Gigliotti \& Santos, 2013). The invasion of protected forested areas by illegal dwellings common in this region (Gigliotti \& Santos, 2013). Initially occupying plains, human households gradually started to invade the slopes of the

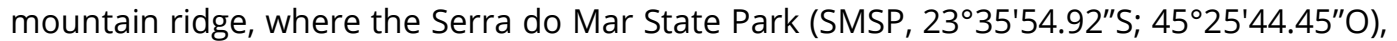
created in 1977 to preserve the slopes of the native rainforest and comprising an area of $315,390.69 \mathrm{ha}$, is located. Currently, illegal settlement in this protected area still occurs (IBGE, 2017). In this area, few epidemiological studies were conducted, especially those focused on the context of the relationship between wildlife and domestic fauna.

The geographical limits of the Serra do Mar State Park were obtained from the Brazilian Ministry of Environment, and a thematic map was produced using Quantum GIS software. Three distinct study areas were selected according to the following criteria: topographic gradient (from sedimentary plains to low- and high slope mountains) and access by roads and trails. After this stage, a pilot campaign was carried out in July 2014 to evaluate the following factors: (a) area history (expropriation, cultivation, irregular and regular housing, social strata of residents) and (b) presence of dogs in four conditions: supervised (owned and restricted), partially supervised (owned but allowed to roam freely), unsupervised (without defined owner) or stray. The definitive locations of the study areas are shown in Figure 1. 


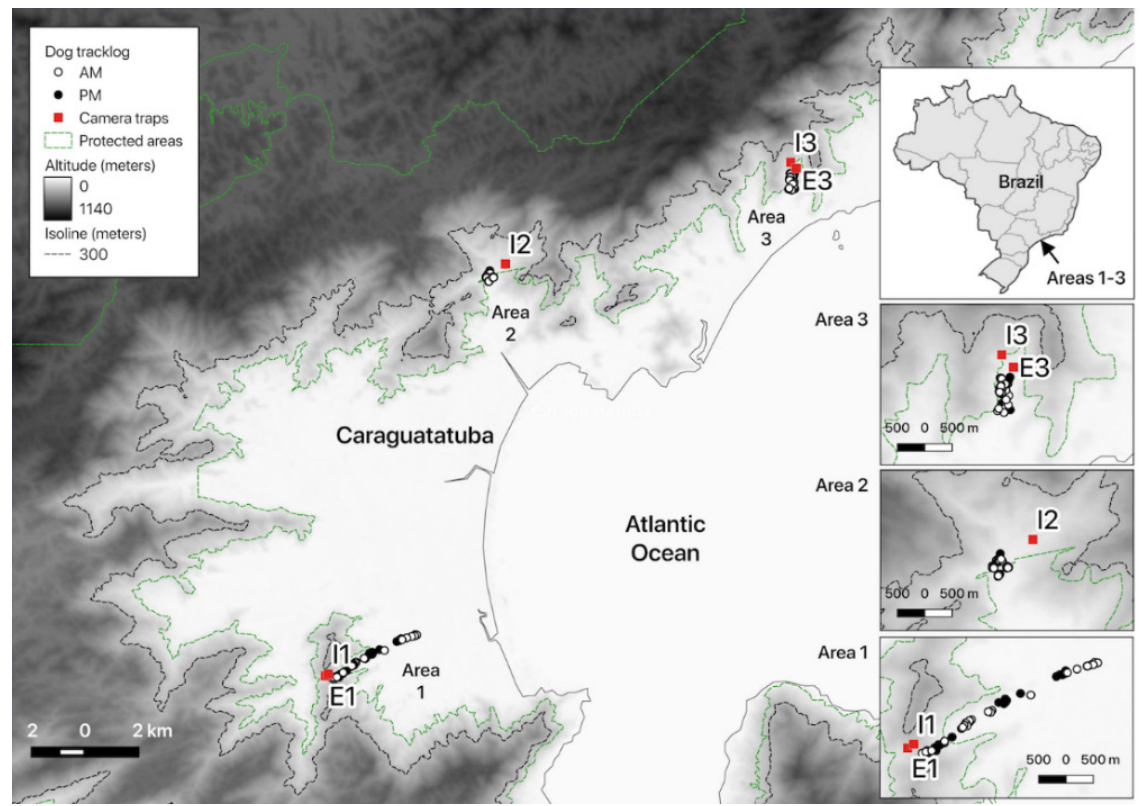

Figure 1. Maps of monitored areas with tracking locations of dogs monitored by GPS collars during the period of monitoring and location of the cameras in 2015 and 2016. Caraguatatuba - SP, Brazil.

\section{Dog sampling}

During the first campaign, in June 2015, a qualitative questionnaire was applied to the dog owners to define the profile of each dog and its role in the human community (Table 1). Through this questionnaire, sought to define the role of each monitored dog in each area as: companion dog (that dog that accompanies their owners when they go to the forest), hunting dog (those dogs that only accompany the owner when they go hunting) or guard (that dog used to protect the house).

Table 1. Proportions of answers to the questionnaire given to dog owners, Caraguatatuba, Brazil.

\begin{tabular}{|c|c|c|c|c|}
\hline Owners' responses & $\begin{array}{l}\text { Area } 1 \\
(n=26)\end{array}$ & $\begin{array}{l}\text { Area } 2 \\
(n=25)\end{array}$ & $\begin{array}{l}\text { Area } 3 \\
(n=27)\end{array}$ & $\begin{array}{c}\text { Chi-square } \\
\text { comparisons } \\
\text { (p-value) }\end{array}$ \\
\hline $\begin{array}{l}\text { Dog was let free (off the property) all the } \\
\text { time }\end{array}$ & $24(92 \%)$ & $9(36 \%)$ & $7(26 \%)$ & 0.02 \\
\hline $\begin{array}{l}\text { Dog was let free only at certain times of the } \\
\text { day }\end{array}$ & $0(0 \%)$ & $11(44 \%)$ & $11(40.7 \%)$ & 0.007 \\
\hline The dog was never let free & $2(7.7 \%)$ & $3(12 \%)$ & $6(22.2 \%)$ & 0.40 \\
\hline $\begin{array}{l}\text { The dog had access to the forest during the } \\
\text { period when it was let loose }\end{array}$ & $24(92 \%)$ & $18(72 \%)$ & $16(59.3 \%)$ & 0.58 \\
\hline $\begin{array}{l}\text { The dog had access to the interior of the } \\
\text { house }\end{array}$ & $10(38.5 \%)$ & $13(52 \%)$ & $16(59.3 \%)$ & 0.67 \\
\hline $\begin{array}{l}\text { The dog was vaccinated during the } \\
\text { monitoring year }\end{array}$ & $15(57.7 \%)$ & $23(92 \%)$ & $26(96.3 \%)$ & 0.43 \\
\hline $\begin{array}{l}\text { The dog was sterilised or used } \\
\text { contraceptive drugs }\end{array}$ & $0(0 \%)$ & $5(20 \%)$ & $13(48.1 \%)$ & 0.004 \\
\hline $\begin{array}{l}\text { The dog used a collar or some method to } \\
\text { eliminate ectoparasites }\end{array}$ & $0(0 \%)$ & $2(8 \%)$ & $20(74.0 \%)$ & $<0.001$ \\
\hline The dog was used as guardian of the house & $19(73.1 \%)$ & $21(84 \%)$ & $10(37.1 \%)$ & 0.19 \\
\hline The dog was used as a hunter & $17(65.4 \%)$ & $0(0 \%)$ & $0(0 \%)$ & $<0.001$ \\
\hline The dog was considered a companion dog & $6(23.0 \%)$ & $15(60 \%)$ & $19(70.4 \%)$ & 0.10 \\
\hline
\end{tabular}


The inclusion criteria for monitoring dogs were: at least one year old and born and raised in the region, as previously described (Pinter et al., 2008). In each study area, a cohort of 20 dogs was sampled approximately every two months for a total of six occasions until April 2016. During each visit, dogs were evaluated for ticks, and a blood sample was collected in clot-activator vacuum collection tubes (model k50-204S Splabor) for molecular testing for $R$. vitalii in blood clots. Serum was extracted from these same samples and tested by the Indirect Immunofluorescence Assay (IIFA) for anti-R. parkeri antibodies (protocols described below). Collected ticks were identified according to dichotomous keys (Barros-Battesti et al., 2006).

\section{Telemetry data}

In order to check where the dogs accessed the forest, i.e., where partly supervised dogs spent their time, six GPS trackers attached to collars were placed on dogs from the three study areas, with two simultaneous trackers per area. To achieve that, the SMS tracker model GPS-TK102B (CU-TEK), which contained both GPS and GSM modules, was used to collect the geographic position (latitude and longitude) and send the coordinates through the GSM network to the researcher's phones. These dogs were selected in such a way as to allow the tracker to be retrieved. Dogs were monitored weekly during the months of October and December 2015. Each dog wore the tracking collar for a maximum period of seven days, and after that, the tracker was removed and placed on another previously selected dog. During the monitoring period, the devices were programmed to send messages with the geographical positions every 30 minutes from $6 \mathrm{pm}$ to $8 \mathrm{am}$ of the following day. In this way, four dogs from each area were monitored.

\section{Photographic records}

From December 2015 to August 2016, four HD Auto-Focus Nature View (BUSHNELL ${ }^{\circledR}$ ) camera traps were used to record wild and domestic animals in the trails used by the tracker-monitored dogs. In Areas 1 and 3 (Figure 1), we installed a camera at the edge of the forest (acronym E, Figure 1), and a second camera was installed inside the forest at 300 meters from the first (acronym I, Figure 1), both in the trails used by the dogs. Every 25 days, the batteries were replaced, and the recorded videos were downloaded and analyzed. Photographic records were also made by two camera traps installed in the edges and inside the forest by other researchers working in the area between 2016-2017. This methodology was used to record any unmonitored dogs, thus avoiding selection bias.

\section{Indirect Immunofluorescence Assay (IIFA)}

Dog sera were tested against antigens of $R$. parkeri (strain At24) to detect reactive antibodies by the Indirect Immunofluorescence Assay (IIFA), as previously described (Labruna et al., 2007). Briefly, sera were diluted in phosphate buffered saline (PBS) and screened at a dilution of 1:64 onto 12-well antigen slides. The slides were incubated, washed, then incubated with fluorescein isothiocyanate-labeled conjugate with anti-dog immunoglobulin G (IgG) (Sigma Diagnostics, St. Luis, MO, USA) and washed again, mounted with buffered glycerin, and read using an ultraviolet microscope (BX60; Olympus Corp., Tokyo, Japan) at 400x magnification. On each slide, a dog serum previously shown to be nonreactive (negative control) from the Department of Medicine Preventive Veterinary and Animal Health of the Faculty of Veterinary Medicine and Zootechnics of the University of Sao Paulo (FMVZ USP) and a serum from an animal naturally infected with $R$. rickettsii with a titer of 1: 8192 (positive control) from the Department of Medicine Preventive Veterinary and Animal Health of the FMVZ USP) were tested at the 1:64 dilution. Serum samples reacting at the screening dilution were tested in serial twofold dilutions to determine the end-point titer. 


\section{Molecular tests}

DNA was extracted from blood clots of samples collected from each dog and from the ticks collected in these animals using a commercial DNA extraction kit (QIAamp DNA Mini Kit, Blood and Tissue ${ }^{\circledR}$ ) according to the manufacturer's instructions (Qiagen) and eluted in $50 \mu \mathrm{L}$ of the buffer included with the extraction kit.

\section{Molecular tests on blood clots - search of Rangelia vitalii}

For detection of $R$. vitalii DNA, we used a species-specific TaqMan real-time PCR system (qPCR) targeting a 179 base pairs (bp) fragment of the $h s p 70$ gene of $R$. vitalii using the primers sense Rv751-770 and antisense Rv930-911 and the $R$. vitalii- specific probe at a concentration of $25 \mu \mathrm{mol} / \mathrm{L}$, as previously described (Soares et al., 2011). For all PCR assays, positive controls (dog blood sample experimentally infected and previously tested) and negative controls (autoclaved DNA-free Milli-Q water) were included. Positive controls for real time PCR reactions were the same as those used by Soares et al. (2018).

\section{Molecular analyses of ticks}

For Rickettsia spp. detection, each DNA sample was tested by PCR using a pair of primers (CS-78 and CS-323) that amplify a $401 \mathrm{bp}$ fragment of the gltA gene, which is present in all species of the genus Rickettsia (Labruna et al., 2004). Samples positive for this gene were tested with a second PCR protocol using a pair of primers (Rr190.70F and Rr190.701R) that amplify a 632 bp fragment of the ompA gene, present only in rickettsiae of the spotted fever group (SFG), as previously described (Regnery et al., 1991; Pacheco et al., 2007). Positive (R. parkeri strain Nod) and negative (autoclaved DNA-free Milli-Q water) controls were included. To ensure sequence quality and confirm species identifications, sequence chromatographs were manually checked and sequence similarity compared to other sequences deposited in GenBank using BLASTN (Basic Local Alignment Search Tool - Nucleotide). The highest quality sequences were deposited at GenBank.

\section{Statistical analysis}

The nonparametric Kruskal-Wallis test was used to compare the canine anti-R. parkeri antibody titers between the study areas per campaign. The Mann-Whithey test with Bonferroni correction was used for post-hoc comparisons. Both analyses were made using a significance level of $5 \%$.

The possible risk factors for $R$. parkeri seroreactivity in dogs were obtained through univariate analysis using the chi-square test. After that, a multivariate analysis was performed using the backward method and the binomial function of generalized linear models using a significance level of $5 \%$. The autocorrelations between the predictors were tested, and the redundant predictors were excluded. All statistical analysis were made in $\mathrm{R}$ (R Core Team, 2017).

\section{Results}

\section{Landscape analysis}

The study areas differed in terms of relief and human occupation (Figure 1). Area 1 was characterized by steep relief, up to 190 meters above sea level. This configuration resulted in considerable complexity in this area, posing restrictions on land use and human occupation. Area 2 was located in the public visitation area of the State Park, being classified as a coastal plain, approximately twelve meters above sea level. Area 3 
was represented by a coastal plain of the State Park, occupied by middle- class condos and holiday houses. The maximum altitude of this area was $20 \mathrm{~m}$ above sea level.

The human occupation in each area was also different. Area 1 presented an irregular occupation, where density diminished with increasing slope and a low-income population occupied the whole area. Area 1 was characterized by lack of basic infrastructure, disordered occupation, construction of new houses without permits and without inspection from the responsible public agencies, and presence of illegal households inside the perimeter of the state park. Most of the residents had informal jobs or performed subsistence agriculture and cattle raising. The presence of small plantations at the edge of the forest was frequently observed. No sewer system was available, and most of the houses had poorly planned septic tanks. The drinking water came from small springs without any sanitary treatment.

Area 2 was equally unorganized, although it had received some urban interventions such as paved streets, retaining walls and drainage. This was the most affected area during the 1967 landslides. After that period, a rapid reoccupation around the Serra do Mar State Park took place. The residents went to this region in search of housing and jobs generated by tourism.

Unlike the other two areas, Area 3 had dwellings on flat land with proper infrastructure. Although the houses were built on the edge of the forest, there were walls or fences delimiting the land. There was a private concierge with security guards, and all residents had to pay a condominium fee. There was public garbage collection, paving of accesses, presence of retaining walls (when necessary) and division of terrains ranging from 180 to 1,000 square meters.

\section{Profiles of monitored dogs and their owners in each area}

Dogs from each area filled three different roles in the community, hunter, guard and companion, in different proportions. These three roles were associated with the socioeconomic and cultural profiles of the owners. All the dog owners of Area 1 performed extractive activities in the forest and had small plantations on the edge of the forest. In Area 2, only one dog owner used the forest edge for plantation. In Area 3, no dog owners used the forest, except for leisure (Table 1).

The dogs considered pets generally remained at home and did not accompany their owners at times that were not exclusive to leisure. It is noteworthy that in Area 1, the same dogs that played the role of hunters were also classified by some of the owners as companion dogs, unlike in Area 2 and Area 3, where no dogs were classified as hunters and all were considered pets and watchdog. In Area 2, dogs played mainly watchdog roles (84\%) and thus rarely followed their owners on walks in the forest, staying near the homes as protectors. In these cases, other dogs or other wild mammals might have been responsible for bringing the ticks to the backyards of these houses, since the houses were in areas surrounding or even within the park.

\section{Telemetry data and photographic records}

Four dogs from each area were monitored through telemetry, totaling 12 dogs. One dog from Area 1 and one from Area 3 were registered up to 300 meters away from the edge inside the forest, where camera traps were subsequently installed (Figure 1). The other ten dogs were registered close to urban areas. In certain regions, the SMS tracker was unable to return location results.

During the study period, the camera traps recorded 2,855 photographs and 156 videos. Of these, 38 records were considered medium and large animals ( $\geq 1.0 \mathrm{~kg}$ ), with 22 records of carnivores: Eira barbara, Nasua nasua, Leopardus pardalis, Leopardus sp., Puma concolor and Canis lupus familiaris. People were also recorded walking in the woods along with their dogs in Area 1 and Area 3. In all areas, except for Area 1, records 
of domestic dogs were obtained only by cameras positioned near the edge of the forest (acronyms E1 and E3, Figure 1). In Area 1, there was a dog record obtained by the camera positioned inside the forest (acronym I1, Figure 1). In this area, one of the dogs monitored by telemetry was also recorded inside the forest. All records of dogs alongside humans in Area 1 occurred during the day (AM, Figure 1). On the other hand, dogs registered in Area 3 were recorded on weekends or holidays alongside people who were probably walking towards the waterfall present in this area (Table 2).

Table 2. Dogs registered through camera traps in each area during the monitoring period (2015 to 2016), Caraguatatuba, Brazil.

\begin{tabular}{|c|c|c|c|c|c|c|}
\hline Area & Dog ID & Day of the week & Time & $\begin{array}{c}\text { Trap } 1 \\
\text { (forest edge) }\end{array}$ & $\begin{array}{c}\text { Trap } 2 \\
\text { (forest } \\
\text { interior) }\end{array}$ & $\begin{array}{c}\text { Presence of } \\
\text { humans }\end{array}$ \\
\hline \multirow{6}{*}{1} & 1 & Tuesday & $2: 58$ pm & & $x$ & \\
\hline & 1 & Thursday & $1: 53$ pm & $x$ & & \\
\hline & 1 & Thursday & $6: 10$ pm & $x$ & & \\
\hline & 1 & Thursday & $6: 57$ am & $x$ & & \\
\hline & 1 & Friday & $12: 47 \mathrm{pm}$ & $x$ & & \\
\hline & 1 & Saturday & 11:11 am & $x$ & & $x$ \\
\hline 2 & 2 & Friday & 2:43 pm & $x$ & & \\
\hline \multirow{2}{*}{3} & 3 & Friday (holidays) & 1:37 pm & $x$ & & $x$ \\
\hline & 3 & Saturday & $11: 20 \mathrm{am}$ & $x$ & & $x$ \\
\hline
\end{tabular}

\section{Collection and identification of ticks}

In total, 61 dogs were investigated: 19 (31.1\%) in Area 1, 24 (39.3\%) in Area 2, and $18(29.5 \%)$ in Area 3. A total of 155 adult A. ovale were collected from the dogs in Area 1, 15 in Area 2 and 12 in Area 3, totalizing 182 ticks throughout the study period (Figure 2). No other species of the genus Amblyomma were recorded parasitizing these dogs during the monitoring period. The largest number of ticks collected on the same dog was recorded in Area 1, where 32 adult individuals were collected on a single dog during the sixth monitoring campaign. In the other areas the maximum number of ticks collected was three individuals.

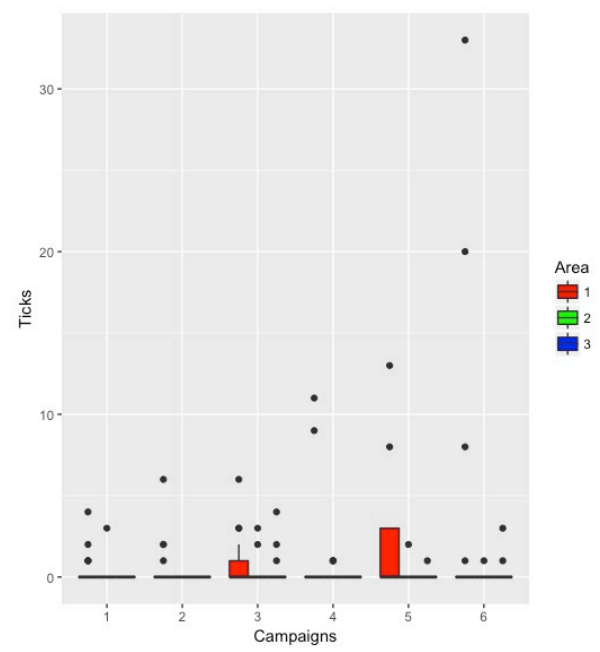

Figure 2. Distribution of the Amblyomma ovale tick counts collected on dogs, by campaign and by area during 2015 and 2016 in Caraguatatuba - SP, Brazil. 


\section{IIFA results for Rickettsia sp. in dogs}

The dogs were monitored at six different campaigns that occurred in June 2015 (campaign 1), August 2015 (campaign 2), October 2015 (campaign 3), December 2015 (campaign 4), February 2016 (campaign 5) and April 2017 (campaign 6). These dogs were visited in all campaigns, and when a dog was withdrawn from the cohort for any reason, a dog with the same profile was included in the study whenever possible (Table 3).

Table 3. Dogs tested for anti-Rickettsia parkeri antibodies during a year of monitoring around Serra do Mar State Park (2015-2016), Caraguatatuba, Brazil.

\begin{tabular}{|c|c|c|c|c|c|c|c|c|}
\hline Season & Campaign & Area & $\begin{array}{c}\text { Monitored } \\
\text { dogs }\end{array}$ & $\begin{array}{c}\text { Dogs } \\
\text { parasitized } \\
\text { by } A \text {. ovale }\end{array}$ & $\begin{array}{c}\text { Ticks } \\
\text { collected }\end{array}$ & $\begin{array}{c}\text { Positive } \\
\text { dogs }\end{array}$ & $\begin{array}{l}\text { Medians } \\
\text { of the } \\
\text { IIFA }\end{array}$ & $\begin{array}{c}\text { Titres } \\
\text { comparison } \\
\text { (p-value) }\end{array}$ \\
\hline \multirow{9}{*}{ Dry } & \multirow{3}{*}{1} & $1^{a}$ & 19 & 3 & 3 & 10 & 64 & \multirow{3}{*}{0.03} \\
\hline & & $2^{b}$ & 24 & 1 & 3 & 3 & 0 & \\
\hline & & $3^{b}$ & 18 & 0 & 0 & 5 & 0 & \\
\hline & \multirow{3}{*}{2} & $1^{a}$ & 17 & 3 & 5 & 14 & 256 & \multirow{3}{*}{0.01} \\
\hline & & $2^{b}$ & 20 & 0 & 0 & 8 & 0 & \\
\hline & & $3^{b}$ & 21 & 0 & 0 & 9 & 0 & \\
\hline & \multirow{3}{*}{3} & $1^{\mathrm{a}}$ & 16 & 7 & 15 & 15 & 384 & \multirow{3}{*}{$<0.01$} \\
\hline & & $2^{b}$ & 20 & 2 & 5 & 12 & 64 & \\
\hline & & $3^{b}$ & 18 & 3 & 7 & 6 & 0 & \\
\hline \multirow{9}{*}{ Rainy } & \multirow{3}{*}{4} & $1^{a}$ & 11 & 2 & 20 & 10 & 512 & \multirow{3}{*}{0.01} \\
\hline & & $2^{b}$ & 18 & 4 & 4 & 11 & 64 & \\
\hline & & $3^{b}$ & 20 & 0 & 0 & 9 & 0 & \\
\hline & \multirow{3}{*}{5} & $1^{a}$ & 16 & 7 & 32 & 15 & 2048 & \multirow{3}{*}{$<0.01$} \\
\hline & & $2^{b}$ & 16 & 1 & 1 & 15 & 256 & \\
\hline & & $3^{b}$ & 18 & 1 & 1 & 13 & 64 & \\
\hline & \multirow{3}{*}{6} & $1^{a}$ & 19 & 3 & 54 & 18 & 1024 & \multirow{3}{*}{$<0.01$} \\
\hline & & $2^{b}$ & 19 & 1 & 1 & 11 & 64 & \\
\hline & & $3^{b}$ & 19 & 2 & 4 & 9 & 0 & \\
\hline
\end{tabular}

Anti- $R$. parkeri reactive antibodies (titers $\geq 64)$ were detected in $91.3 \%(21 / 23)$ of the Area 1 dogs, 72.2\% (13/18) of the Area 2 dogs, and 73.9\% (17/23) of the Area 3 dogs. Of these 51 positive dogs, 22 dogs were already seropositive from the first analysis, 29 dogs became seropositive at some time point during the study, and 12 remained seronegative (titers $<64$ ). The area that presented the highest number of seropositive dogs was Area 1, followed by Areas 3 and 2. Area 1 positive samples showed higher values of antibody titers ( $\geq 64)$ compared to Area 2 in the second $(p=0.018$ ), third $(p=0.0028)$, fourth $(p=0.025)$ and fifth $(p=0.03)$ campaigns and Area 3 in third $(p=0.0015)$, fourth $(p=0.015)$ and fifth $(p=0.00035)$ campaigns. The titers of Areas 2 and 3 showed no significant difference in all campaigns (Figure 3 ). 


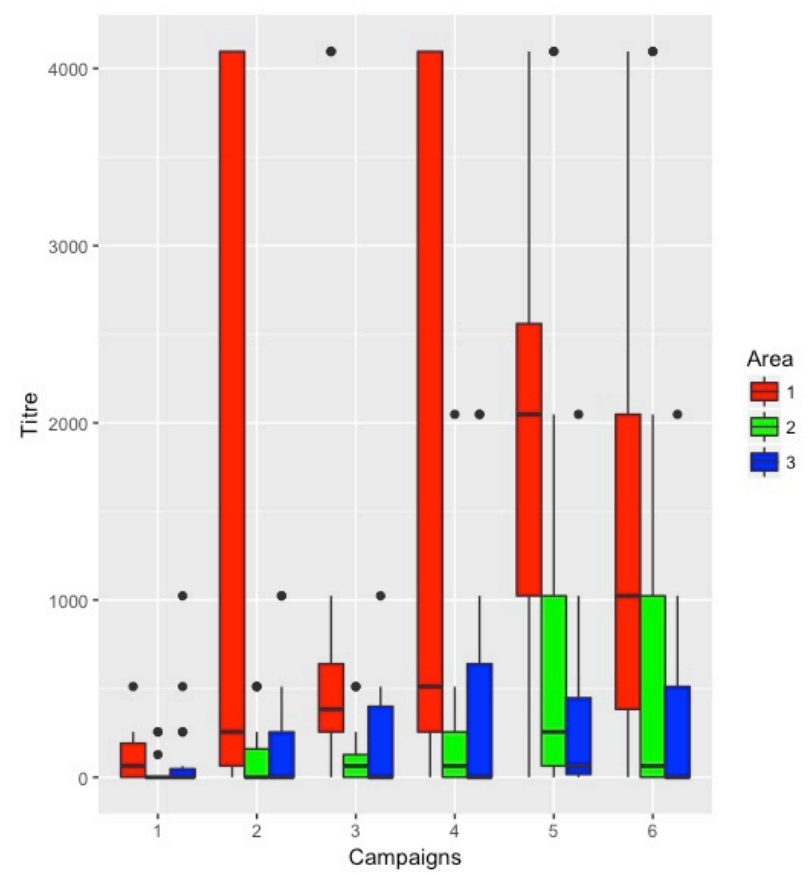

Figure 3. Distribution of anti-Rickettsia parkeri antibody titers by IIFA by campaign (2015-2016) and by collection area in Caraguatatuba - SP, Brazil.

Dogs that had at least one individual $A$. ovale tick collected during the campaigns had a risk of R. parkeri seropositivity 10 times greater than that of dogs that did not have this tick species collected $(p=0.009)$. It was also observed that companion dogs had a risk of $R$. parkeri seropositivity 5.4 times higher than that of non-companion dogs $(p=0.009)$ (Table 4).

Table 4. Univariate and multivariate analyses and odds ratios for Rickettsia parkeri seroreactivity.

\begin{tabular}{lccc}
\hline \multicolumn{1}{c}{ Variables } & $\begin{array}{c}\text { Univariate } \\
\text { analysis } \mathbf{( p )}\end{array}$ & $\begin{array}{c}\text { Multivariate } \\
\text { analysis } \\
\mathbf{( p )}\end{array}$ & $\begin{array}{c}\text { Odds ratio and } \\
\text { confidence } \\
\text { interval (95\%) }\end{array}$ \\
\hline $\begin{array}{l}\text { Study area (A1, A2, A3)* } \\
\text { At least one tick collected during the }\end{array}$ & 0.117 & $>0.050$ & - \\
campaigns & 0.007 & 0.009 & $10.05(2.10 ; 76.47)$ \\
Guard dog & 0.222 & $>0.050$ & - \\
Companion dog & 0.078 & 0.009 & $5.39(1.61 ; 20.32)$ \\
Dog with access to the forest & 0.002 & $>0.050$ & - \\
Dog without movement restriction & 0.008 & $>0.050$ & - \\
Dog occasionally left free & 1.000 & $>0.050$ & - \\
\hline
\end{tabular}

*Reference category: Area 1 (A1).

\section{Molecular tests on blood clots - search of Rangelia vitaliii}

To perform the molecular tests for $R$. vitalii, the clots from the collected blood samples were submitted to a real-time PCR assay targeting $R$. vitalii. The real-time PCR primers tested in the present study were able to amplify a portion of the $R$. vitalii $h s p 70$ gene in all canid blood and tissue samples that were previously shown to contain $R$. vitalii DNA. Agarose gel electrophoresis of these positive samples revealed a single band corresponding to the expected amplicon size (180bp). 
Considering the three replicates of standard curve diluted in canine blood, the sensitivity of the real-time PCR assay was demonstrated to be 25 copies per reaction (limit of quantification). On the other hand, 2.5 copies of the $R$. vitalii hsp70 gene were detected by two of three replicates (limit of detection). The standard curve generated with dilutions of $R$. vitalii hsp70 gene in canine blood DNA samples showed an efficiency of $101.2 \%$ (slope $=-3.294$ ) and a 0.999 coefficient of correlation (R2). The efficiency (E) of reaction was calculated with the formula proposed by Soares et al. (2018):

$$
E=10\left(-\frac{1}{\text { slope }}\right)-1
$$

Only one dog from Area 1 was positive for R. vitalii DNA, during campaigns 3 and 6 . This animal was also positive for IIFA for R. parkeri and was parasitized by A. ovale in three monitoring campaigns. This dog had free access to the forest and was classified as both hunter and companion. The owner of this dog cultivated small crops at the edge of the forest and carried out extractive activities in the forest for subsistence.

\section{Molecular analyses of ticks}

A total of 182 ticks were submitted to DNA extraction, of which 35 specimens of A. ovale fragments of the rickettsia gltA gene were amplified by PCR, 27 (17.4\%) came from dogs from area 1, 2 (13.3\%) from dogs from area 2 and 6 (50.0\%) from dogs from area 3. Finally, these amplifiers were subjected to a new PCR for the ompA Rickettsia gene. Ten ticks collected from seven different dogs (five from Area 1 and two from Area 3) yielded PCR fragments for the ompA gene (Table 5). Amplicons from these ticks were DNA-sequenced and were $100 \%$ identical to $R$. parkeri strain Atlantic rainforest clone Ad106 (GenBank accession number MF536975).

Table 5. Tick samples positive for the gltA and ompA genes in each area per campaign in the monitoring period (2015-2016), Caraguatatuba, Brazil.

\begin{tabular}{|c|c|c|c|c|c|c|c|c|c|c|}
\hline \multirow[t]{2}{*}{ Dog } & \multirow[t]{2}{*}{ IFA } & \multirow[t]{2}{*}{ Area } & \multicolumn{6}{|c|}{$\begin{array}{l}\text { Number of the positive ticks for } \\
\text { campaigns }\end{array}$} & \multirow[t]{2}{*}{ ompA } & \multirow[t]{2}{*}{ Total } \\
\hline & & & C1 & C2 & C3 & C4 & C5 & C6 & & \\
\hline 0039 & Positive & 1 & 0 & 0 & 0 & 0 & 3 & 0 & amplified & 3 \\
\hline 2954 & Positive & 1 & 2 & 0 & 0 & 2 & 3 & 0 & amplified & 7 \\
\hline 0036 & Positive & 1 & 0 & 1 & 0 & 0 & 0 & 0 & - & 1 \\
\hline 2968 & Positive & 1 & 0 & 0 & 5 & 0 & 0 & 0 & amplified & 5 \\
\hline 2966 & Positive & 1 & 0 & 0 & 1 & 0 & 0 & 0 & - & 1 \\
\hline 2967 & - & 1 & 0 & 0 & 3 & 0 & 0 & 0 & amplified & 3 \\
\hline 2960 & Positive & 1 & 0 & 0 & 0 & 0 & 3 & 0 & amplified & 3 \\
\hline 0042 & Positive & 1 & 0 & 0 & 0 & 0 & 2 & 0 & - & 2 \\
\hline 0048 & Positive & 1 & 0 & 1 & 0 & 0 & 0 & 1 & - & 2 \\
\hline 3090 & Positive & 2 & 1 & 0 & 0 & 0 & 0 & 0 & - & 1 \\
\hline 7087 & Positive & 2 & 0 & 0 & 0 & 1 & 0 & 0 & - & 1 \\
\hline 3008 & Positive & 3 & 1 & 0 & 0 & 0 & 0 & 0 & amplified & 1 \\
\hline 3108 & Positive & 3 & 1 & 0 & 2 & 0 & 0 & 0 & amplified & 3 \\
\hline 2964 & Positive & 3 & 0 & 0 & 2 & 0 & 0 & 0 & - & 2 \\
\hline $\begin{array}{l}\text { Total positive } \\
\text { ticks }\end{array}$ & & & 5 & 2 & 13 & 3 & 11 & 1 & - & 35 \\
\hline
\end{tabular}




\section{Discussion}

The harms caused by dogs in forests have been widely discussed (Galetti \& Sazima, 2006; Srbek-Araujo \& Chiarello, 2008; Torres \& Prado, 2010; Ogrzewalska et al., 2012; Martinez et al., 2013). Several authors have characterized the dog as an animal that is highly adaptable to the wilderness and that can easily develop feral habits (Galetti \& Sazima, 2006; Frigeri et al., 2014). in this study, it was observed that the relation of the dog to the wild environment is strongly correlated to the owner's way of life. In this scenario, a dog that had free access to the forest did not necessarily develop feral habits. It was observed that dogs, when living freely, tended to walk into the forest only through the same areas used by their owners spatially and temporally as a follower.

In a recent study carried out in areas of Atlantic rainforest, it was observed that dog visits in agroforestry areas were associated with the times and days when humans were active in the same place, showing that there was a mutual companionship between dogs and their owners (Frigeri et al., 2014). In this present study, this association also seemed to occur in Area 1, where dogs accompanied their owners for hunting, during extractive activities and in recreational activities on the edges of the forest.

Through telemetry recorders placed on the dogs, it was possible to observe that dogs tended to stay at home with their owners at night and accompanied them in daytime activities whenever allowed by the humans. The results obtained by this equipment were limited. However, they point to this companionship between the dog and its owner in the forest. In Area 1, every time that a local resident was registered in the forest through a camera trap, a dog was accompanying him. This result is also indicative of this association.

The statistical analyses showed that companion dogs were at 5.4 times higher risk of exposure to SFG Rickettsia than those not considered companions $(p=0.009)$. Through questionnaires and field observations, it was possible to determine that companion dogs showed different behaviors than pet and watchdogs. Companion dogs usually had full access to the forest, performed some work for their owners and accompanied them most of the time that they stayed in the forest.

The seropositivity for R. parkeri was slightly higher in Area 1 than in the other two areas (Area $1=91.3 \%$, Area $2=72.2 \%$, and Area $3=73.9 \%$ ). In Area 1, most dogs were considered companions and lived freely $(n=92 \%)$, entering the forest at any time and thus being potentially exposed to ticks. The human presence within the forest was associated with the way of life of the people who inhabited this environment because they developed small crops and used the forest for extractive activities.

It is very likely that dogs followed their owners during these walks, which allowed the contact to the tick $A$. ovale. Thus, even for the dogs that stayed at home with their owners most of the time, hiking into the forest exposed these animals to tick infestation. This result is supported by the high number of seropositive animals that did not have a compatible profile, which would imply access to the forest, but that were considered companion dogs in Area 3. That is, those owners who use the forest only for laser and take their dogs at these times.

The high seropositivity observed in the dogs of all studied areas showed that Serra do Mar State Park is an endemic area for SFG Rickettsia infection, most likely due to R. parkeri strain Atlantic rainforest, which was detected in $A$. ovale, the dominant tick species in the study area. This assumption highlights the risks of transmission of Rickettsia to humans in this area, since A. ovale is a well-known human- biting tick (Szabó et al., 2013; Barbieri et al., 2014).

In laboratory tests, adults of $A$. aureolatum infected with $R$. rickettsii in its virulent state (reactivated), are able to transmit the pathogen to the host within ten minutes after being attached (Saraiva et al., 2014). This association may also be valid for $A$. ovale, which is phylogenetically closely related to $A$. aureolatum and shares similar life habits in adult stages (Aragão \& Fonseca, 1961; Guglielmone et al., 2003b). This fact may suggest that a 
single contact with an infected tick in these conditions may be sufficient for dogs to demonstrate positive results in IIFA for rickettsiosis in the Atlantic Forest. In this study, it was shown that dogs that had at least one individual of $A$. ovale collected during the campaigns had a risk of $R$. parkeri seropositivity ten times greater than that of those who did not have any $A$. ovale collected $(p=0.009$ ). Additionally, was observed that in Area 1, where dogs had more frequent contacts with the forest and higher abundance of $A$. ovale parasitism, the IIFA seropositivity titers for $R$. parkeri showed differences in relation to the other two areas. These results reinforce the hypotheses that dogs play an important role in maintaining the population of the tick $A$. ovale and perhaps the bacterium $R$. parkeri strain Atlantic rainforest and its vectors. However, they cannot be considered the only source of infection, since people entering the forest with their dogs are exposed to tick parasitism at the same time.

A study published by Krawczak et al. (2016) showed that A. ovale can perform transovarial transmission and transstadial perpetuation of $R$. parkeri Atlantic rainforest strain for at least two generations. This study strongly supports the clinical and epidemiological data implicating $A$. ovale ticks as the main vector of $R$. parkeri Atlantic rainforest strain in the endemic areas observed in Brazil to date (Sabatini et al., 2010; Spolidorio et al., 2010; Krawczak et al., 2016).

Engorged A. ovale females infected with Rickettsia sp. strain Atlantic rainforest have a relatively high mortality rate and lower reproductive performance, as is true for other species of the genus Rickettsia and other species of ticks (Burgdorfer \& Brinton, 1975; Labruna et al., 2011; Krawczak et al., 2016; Schumacher et al., 2016). Thus, very low rates of Rickettsia infection may be related to the expressiveness of infected females that survive (Labruna et al., 2011). In the case of $R$. parkeri strain Atlantic rainforest, the rate of infection of $A$. ovale ticks in Atlantic Forest areas is approximately $10 \%$, which is relatively high in relation to $R$. rickettsia in endemic areas (<1\%) (Sabatini et al., 2010; Szabó et al., 2012; Krawczak et al., 2016). Thus, it is possible that the horizontal transmission of $R$ parkeri strain Atlantic rainforest among nymphs $A$. ovale ticks plays an important role in sustaining this pathogen in its endemic areas. Furthermore, the fact that vertebrate species must play the role of amplifier of the bacteria is strongly defended (Labruna et al., 2011; Krawczak et al., 2016).

These facts are not valid for $R$. vitalii, which was also analyzed in this study. Even so, the presence of only one domestic dog positive for $R$. vitalii infection is an interesting finding because this protozoan uses $A$. aureolatum as its only known vector (Gottlieb et al., 2016; Lemos et al., 2017; Soares et al., 2018). Noteworthy, the dog that presented infection by $R$. vitalii was also seropositive for $R$. parkeri. This dog was monitored throughout the forest. Her owner also used to enter into the forest to collect, hunt, and harvest for survival. Amblyomma ovale specimens were collected in this dog in three of the six monitoring campaigns. The large infestation observed in this dog may be associated with the owner's livelihood and dependence on the forest to survive, where the dog may have been parasitized by $A$. aureolatum at any given time.

Cultural diversity and the discrepancy between social classes and the Serra do Mar State Park in the city of Caraguatatuba showed that dogs develop their habits and are closely linked to the life styles of their owners. These factors may be associated with the occurrence of parasite outbreaks and the presence of wild parasitism (Labruna et al., 2001; Passos, et al., 2005; Ogrzewalska et al., 2012; Vieira et al., 2013; Saraiva et al., 2014). The changes in economic and social relationships established in Brazilian urban areas contributed to the role change from farm dogs to urban dogs (Martinez et al., 2013). However, peculiarities of this human-dog relationship, such as the aspect of companionship, open a discussion regarding at what point and in which locations dogs should be allowed to follow their owners into the protected forest patches. It is known that humans can be parasitized by adults of $A$. ovale and $A$. aureolatum, but at a very low intensity, generally, by only one tick (Barbieri et al., 2014; Saraiva et al., 2014). However, 
large infestations of these ticks do occur in dogs (Guglielmone et al., 2003a; Ogrzewalska et al., 2012; Martins et al., 2012; Maturano et al., 2015). In this study, more than 30 individuals of $A$. ovale were collected from a single dog in Area 1.

In the Atlantic Forest, dogs can transport infected ticks into households and increase the risk of transmission of $R$. parkeri strain Atlantic rainforest to the people with close contact with the dogs (Ogrzewalska et al., 2012; Saraiva et al., 2014). In this context, it is important that the owners, regardless of social class, are aware that domestic dogs should stay out of the forest areas, at home, for the health of the families that live with them and to preserve the ecological balance of the forest.

The results of the tick analyses and the high $R$. parkeri seropositivity observed in the dogs of all studied areas highlight an endemicity for SFG Rickettsia caused by R. parkeri strain Atlantic rainforest in Serra do Mar State Park. The presence of dogs in this environment may increase the risk of transmission to humans and play an important role in the epidemiological cycle of perpetuation and transmission of the Rickettsia pathogen.

\section{Acknowledgements}

This work was supported by Fundação de Amparo à Pesquisa do Estado de São Paulo (FAPESP process 2014/00648-3). Also the contributions of the Superintendência de Estadual de Controle de Endemias de São Paulo (SUCEN) and the team of State Park Serra do Mar were fundamental. This study was financed in part by the Coordenação de Aperfeiçoamento de Pessoal de Nível Superior - Brasil (CAPES) - Finance Code 001.

\section{References}

Aragão H, Fonseca F. Notas de ixodologia. IX. O complexo ovale do gênero Amblyomma. Mem Inst Oswaldo Cruz 1961; 59(2): 131-148. http://dx.doi.org/10.1590/S0074-02761961000200002. PMid:13861961.

Barbieri A, Filho MJ, Nieri-Bastos FA, Souza JC Jr, Szabó MPJ, Labruna MB. Epidemiology of Rickettsia sp. strain Atlantic rainforest in a spotted fever- endemic area of southern Brazil. Ticks Tick Borne Dis 2014; 5(6): 848-853. http://dx.doi.org/10.1016/j.ttbdis.2014.07.010. PMid:25108786.

Barros-Battesti DM, Arzua M, Bechara GH. Carrapatos de importância médico-veterinária da Região Neotropical: um guia ilustrado para identificação de espécies. 1a ed. São Paulo: Vox/ICTTD3/Butantan; 2006.

Burgdorfer W, Brinton LP. Mechanisms of transovarial infection of spotted fever Rickettsiae in ticks. Ann N Y Acad Sci 1975; 266(1): 61-72. http://dx.doi.org/10.1111/j.1749-6632.1975.tb35088.x. PMid:829476.

Carini A. Notícias sobre zoonoses observadas no Brasil. Rev Med 1908; 22: 459-462.

Chapman A, Bakken J, Folk SM, Paddock C, Bloch KC, Krusell A, et al. Diagnosis and management of tickborne rickettsial diseases: Rocky Mountain spotted fever, ehrlichioses, and anaplasmosis United States: a practical guide for physicians and other health-care and public health professionals. MMWR Recomm Rep 2006; 55(RR-4): 1-27. PMid:16572105.

Doherty TS, Dickman CR, Glen AS, Newsome TM, Nimmo DG, Ritchie EG, et al. The global impacts of domestic dogs on threatened vertebrates. Biol Conserv 2017; 210: 56-59. http://dx.doi.org/10.1016/j.biocon.2017.04.007.

Ferreira CGT, Bezerra ACDS, Carvalho OV, Almeida MR, Mafra C. First occurrence of Amblyomma ovale in the State of Rio Grande do Norte, Brazil. Rev Bras Parasitol Vet 2013; 22(1): 167-170. http://dx.doi.org/10.1590/S1984-29612013000100032. PMid:24252966.

Fiorello CV, Noss AJ, Deem SL. Demography, hunting ecology, and pathogen exposure of domestic dogs in the Isoso of Bolivia. Conserv Biol 2006; 20(3): 762-771. http://dx.doi.org/10.1111/j.15231739.2006.00466.x. PMid:16909569.

Frigeri E, Cassano CR, Pardini R. Domestic dog invasion in an agroforestry mosaic in southern Bahia, Brazil. Trop Conserv Sci 2014; 7(3): 508-528. http://dx.doi.org/10.1177/194008291400700310. 
Galetti M, Sazima I. Impact of feral dogs in an urban Atlantic forest fragment in southeastern Brazil. Nat Conserv 2006; 4(1): 146-151.

Gigliotti C, Santos MJ. A expansão urbana de Caraguatatuba (1950-2010): uma análise das transformações sócio espaciais. Caminhos de Geografia 2013; 14(46): 150-159.

Gottlieb J, André MR, Soares JF, Gonçalves LR, Oliveira MT, Costa MM, et al. Rangelia vitalii, Babesia spp. and Ehrlichia spp. in dogs in Passo Fundo, State of Rio Grande do Sul, Brazil. Rev Bras Parasitol Vet 2016; 25(2): 172-178. http://dx.doi.org/10.1590/S1984-29612016041. PMid:27334817.

Guglielmone AA, Estrada Peña A, Keirans JE, Robbins R. Ticks (Acari: Ixodida) of the Neotropical. Ticks (Acari: Ixodida) of the Neotropical Zoogeographic Region. Atlanta, Houten: International Consortium on Ticks and Tickborne Diseases (ICTTD-2); 2003a.

Guglielmone AA, Estrada-Peña A, Mangold AJ, Barros-Battesti DM, Labruna MB, Martins JR, et al. Amblyomma aureolatum (Pallas, 1772) and Amblyomma ovale Koch, 1844 (Acari: Ixodidae): Hosts, distribution and 16S rDNA sequences. Vet Parasitol 2003b; 113(3-4): 273-288. http://dx.doi.org/10.1016/S0304-4017(03)00083-9. PMid:12719142.

Instituto Brasileiro de Geografia e Estatística - IBGE. Brasil em Síntese [online]. Rio de Janeiro: IBGE; 2017 [cited 2017 Oct 7]. Available from: https://cidades.ibge.gov.br/brasil/sp/caraguatatuba/panorama

Krawczak FS, Agostinho WC, Polo G, Moraes-Filho J, Labruna MB. Comparative evaluation of Amblyomma ovale ticks infected and noninfected by Rickettsia sp. strain Atlantic rainforest, the agent of an emerging rickettsiosis in Brazil. Ticks Tick Borne Dis 2016; 7(3): 502-507. http://dx.doi.org/10.1016/j.ttbdis.2016.02.007. PMid:26895674.

Labruna MB, Horta MC, Aguiar DM, Cavalcante GT, Pinter A, Gennari SM, et al. Prevalence of Rickettsia infection in dogs from the urban and rural areas of Monte Negro municipality, western Amazon, Brazil. Vector Borne Zoonotic Dis 2007; 7(2): 249-255. http://dx.doi.org/10.1089/vbz.2006.0621. PMid:17627445.

Labruna MB, Ogrzewalska M, Soares JF, Martins TF, Soares HS, Moraes-Filho J, et al. Experimental Infection of Amblyomma aureolatum Ticks with Rickettsia rickettsii. Emerg Infect Dis 2011; 17(5): 829-834. http://dx.doi.org/10.3201/eid1705.101524. PMid:21529391.

Labruna MB, Souza SLP, Guimarães JS Jr, Pacheco RC, Pinter A, Gennari SM. Prevalência de carrapatos em cães de áreas rurais da região norte do Estado do Paraná. Arq Bras Med Vet Zootec 2001; 53(5): 553-556. http://dx.doi.org/10.1590/S0102-09352001000500007.

Labruna MB, Whitworth T, Horta MC, Bouyer DH, McBride JW, Pinter A, et al. Rickettsia species infecting Amblyomma cooperi ticks from an area in the state of São Paulo, Brazil, where Brazilian spotted fever is endemic. J Clin Microbio/ 2004; 42(1): 90-98. http://dx.doi.org/10.1128/JCM.42.1.90-98.2004. PMid:14715737.

Lemos TD, Toma HK, Assad RQ, Silva AV, Corrêa RGB, Almosny NRP. Clinical and hematological evaluation of Rangelia vitalii- naturally infected dogs in southeastern Brazil. Rev Bras Parasitol Vet 2017; 26(3): 307-313. http://dx.doi.org/10.1590/s1984-29612017040. PMid:28902259.

Lessa I, Guimarães TCS, Bergallo HG, Cunha A, Vieira EM. Domestic dogs in protected areas: a threat to Brazilian mammals? Nat Conserv 2016; 14(2): 46-56. http://dx.doi.org/10.1016/j.ncon.2016.05.001.

Londoño AF, Díaz FJ, Valbuena G, Gazi M, Labruna MB, Hidalgo M, et al. Infection of Amblyomma ovale by Rickettsia sp. strain Atlantic rainforest, Colombia. Ticks Tick Borne Dis 2014; 5(6): 672-675. http://dx.doi.org/10.1016/j.ttbdis.2014.04.018. PMid:25090976.

Malheiros J, Costa MM, Amaral RB, Sousa KCM, André MR, Machado RZ, et al. Identification of vectorborne pathogens in dogs and cats from Southern Brazil. Ticks Tick Borne Dis 2016; 7(5): 893-900. http://dx.doi.org/10.1016/j.ttbdis.2016.04.007. PMid:27266811.

Martinez E, Cesário C, Oliveira e Silva I, Boere V. Domestic dogs in rural area of fragmented Atlantic Forest: potential threats to wild animals. Cienc Rural 2013; 43(11): 1998-2003. http://dx.doi.org/10.1590/S0103-84782013001100013.

Martins TF, Moura MM, Labruna MB. Life-cycle and host preference of Amblyomma ovale (Acari: Ixodidae) under laboratory conditions. Exp Appl Acarol 2012; 56(2): 151-158. http://dx.doi.org/10.1007/s10493-011-9506-9. PMid:22113779. 
Maturano R, Faccini JH, Daemon E, Fazza PC, Bastos R. Additional information about tick parasitism in Passeriformes birds in an Atlantic Forest in southeastern Brazil. Parasitol Res 2015; 114(11): 4181-4193. http://dx.doi.org/10.1007/s00436-015-4651-4. PMid:26253798.

Mongruel ACB, Ikeda P, Sousa KCM, Benevenute JL, Falbo MK, Machado RZ, et al. Molecular detection of vector borne pathogens in anemic and thrombocytopenic dogs in southern Brazil. Rev Bras Parasitol Vet 2018; 27(4): 505-513. http://dx.doi.org/10.1590/s1984-296120180069. PMid:30462822.

Moreira L, Vilardo M, Bitencourt Guimarães L, Freitas Silva J, Melo Ocarino N, Serakides R, et al. Infecção por Rangelia vitalii em um cão em Minas Gerais. Arch Vet Sci 2013; 18(3): 637-639.

Nieri-Bastos FA, Marcili A, Sousa R, Paddock CD, Labruna MB. Phylogenetic Evidence for the existence of multiple strains of Rickettsia parkeri in the new world. Appl Environ Microbiol 2018; 84(8): e02872-e17. http://dx.doi.org/10.1128/AEM.02872-17. PMid:29439989.

Ogrzewalska M, Saraiva DG, Moraes-Filho J, Martins TF, Costa FB, Pinter A, et al. Epidemiology of Brazilian spotted fever in the Atlantic Forest, State of São Paulo, Brazil. Parasitology 2012; 139(10): 1283-1300. http://dx.doi.org/10.1017/S0031182012000546. PMid:22716923.

Pacheco RC, Horta MC, Moraes-Filho J, Ataliba AC, Pinter A, Labruna MB. Rickettsial infection in capybaras (Hydrochoerus hydrochaeris) from São Paulo, Brazil: serological evidence for infection by Rickettsia bellii and Rickettsia parkeri. Biomedica 2007; 27(3): 364-371. http://dx.doi.org/10.7705/biomedica.v27i3.199. PMid:18320102.

Paschoal AMO, Massara RL, Santos JL, Chiarello AG. Is the domestic dog becoming an abundant species in the Atlantic forest? A study case in southeastern Brazil. Mammalia 2012; 76(1): 67-76. http://dx.doi.org/10.1515/mammalia-2012-0501.

Passos LMF, Geiger SM, Ribeiro MFB, Pfister K, Zahler-Rinder M. First molecular detection of Babesia vogeli in dogs from Brazil. Vet Parasitol 2005; 127(1): 81-85. http://dx.doi.org/10.1016/j.vetpar.2004.07.028. PMid:15619377.

Pestana BR. O nambiuvú. Rev Med 1910; 22: 423-426.

Pinter A, Horta MC, Pacheco RC, Moraes-Filho J, Labruna MB. Serosurvey of Rickettsia spp. in dogs and humans from an endemic area for Brazilian spotted fever in the State of São Paulo, Brazil. Cad Saude Publica 2008; 24(2): 247-252. http://dx.doi.org/10.1590/S0102-311X2008000200003. PMid:18278271.

R Development Core Team - R Core Team. R: a language and environment for statistical computing. Version 3.4.3. $R$ Foundation for Statistical Computing. Vienna, Austria: R Core Team; 2017.

Regnery RL, Spruill CL, Plikaytis BD. Genotypic identification of Rickettsiae and estimation of intraspecies sequence divergence for portions of two rickettsial genes. J Bacterio/ 1991; 173(5): 1576-1589. http://dx.doi.org/10.1128/JB.173.5.1576-1589.1991. PMid:1671856.

Sabatini GS, Pinter A, Nieri-Bastos FA, Marcili A, Labruna MB. Survey of ticks (Acari: Ixodidae) and their Rickettsia in an Atlantic rain forest reserve in the State of São Paulo, Brazil. J Med Entomol 2010; 47(5): 913-916. http://dx.doi.org/10.1093/jmedent/47.5.913. PMid:20939390.

Saito TB, Cunha-Filho NA, Pacheco RC, Ferreira F, Pappen FG, Farias NAR, et al. Canine infection by Rickettsiae and Ehrlichiae in Southern Brazil. Am J Trop Med Hyg 2008; 79(1): 102-108. http://dx.doi.org/10.4269/ajtmh.2008.79.102. PMid:18606772.

Saraiva DG, Soares HS, Soares JF, Labruna MB. Feeding period required by Amblyomma aureolatum ticks for transmission of Rickettsia rickettsii to vertebrate hosts. Emerg Infect Dis 2014; 20(9): 1504-1510. http://dx.doi.org/10.3201/eid2009.140189. PMid:25148391.

Schumacher L, Snellgrove A, Levin ML. Effect of Rickettsia rickettsii (Rickettsiales: Rickettsiaceae) ilnfection on the biological parameters and survival of its tick vector - Dermacentor variabilis (Acari: Ixodidae). J Med Entomo/ 2016; 53(1): 172-176. http://dx.doi.org/10.1093/jme/tjv166. PMid:26494822.

Soares JF, Costa FB, Girotto-Soares A, Silva AS, França RT, Taniwaki SA, et al. Evaluation of the vector competence of six ixodid tick species for Rangelia vitalii (Apicomplexa, Piroplasmorida), the agent of canine rangeliosis. Ticks Tick Borne Dis 2018; 9(5): 1221-1234. http://dx.doi.org/10.1016/j.ttbdis.2018.05.004. PMid:29752143. 
Soares JF, Dall'Agnol B, Costa FB, Krawczak FS, Comerlato AT, Rassato BCD, et al. Natural infection of the wild canid, Cerdocyon thous, with the piroplasmid Rangelia vitalii in Brazil. Vet Parasitol 2014; 202(3-4): 156-163. http://dx.doi.org/10.1016/j.vetpar.2014.02.058. PMid:24685025.

Soares JF, Girotto A, Brandão PE, Silva AS, França TR, Lopes STA, et al. Detection and molecular characterization of canine piroplasm from Brazil. Vet Parasitol 2011; 180(3-4): 203-208. http://dx.doi.org/10.1016/j.vetpar.2011.03.024. PMid:21489694.

Soares JF, Soares HS, Barbieri AM, Labruna MB. Experimental infection of the tick Amblyomma cajennense, Cayenne tick, with Rickettsia rickettsii, the agent of Rocky Mountain spotted fever. Med Vet Entomol 2012; 26(2): 139-151. http://dx.doi.org/10.1111/j.1365-2915.2011.00982.x. PMid:22007869.

Spolidorio MG, Labruna MB, Mantovani E, Brandão PE, Richtzenhain LJ, Yoshinari NH. Novel spotted fever group rickettsiosis, Brazil. Emerg Infect Dis 2010; 16(3): 521-523. http://dx.doi.org/10.3201/eid1603.091338. PMid:20202436.

Srbek-Araujo AC, Chiarello AG. Domestic dogs in Atlantic forest preserves of south-eastern Brazil: A camera-trapping study on patterns of entrance and site occupancy rates. Braz J Biol 2008; 68(4): 771-779. http://dx.doi.org/10.1590/S1519-69842008000400011. PMid:19197494.

Szabó MPJ, Martins TF, Nieri-Bastos FA, Spolidorio MG, Labruna MB. A surrogate life cycle of Amblyomma ovale Koch, 1844. Ticks Tick Borne Dis 2012; 3(4): 262-264. http://dx.doi.org/10.1016/j.ttbdis.2012.06.002. PMid:22910060.

Szabó MPJ, Nieri-Bastos FA, Spolidorio MG, Martins TF, Barbieri AM, Labruna MB. In vitro isolation from Amblyomma ovale (Acari: Ixodidae) and ecological aspects of the Atlantic rainforest Rickettsia, the causative agent of a novel spotted fever rickettsiosis in Brazil. Parasitology 2013; 140(6): 719-728. http://dx.doi.org/10.1017/S0031182012002065. PMid:23363571.

Torres PC, Prado PI. Domestic dogs in a fragmented landscape in the Brazilian Atlantic Forest: Abundance, habitat use and caring by owners. Braz J Biol 2010; 70(4): 987-994. http://dx.doi.org/10.1590/S1519-69842010000500010. PMid:21180903.

Udell MA, Wynne CDL. A Review of Domestic Dogs' (Canis familiaris) human-like behaviors: Or why behavior analysts should stop worrying and love their dogs. J Exp Anal Behav 2008; 89(2): 247261. http://dx.doi.org/10.1901/jeab.2008.89-247. PMid:18422021.

Vieira TSWJ, Vieira RFC, Nascimento DAG, Tamekuni K, Toledo RS, Chandrashekar R, et al. Serosurvey of tick-borne pathogens in dogs from urban and rural areas from Parana State, Brazil. Rev Bras Parasitol Vet 2013; 22(1): 104-109. http://dx.doi.org/10.1590/S1984-29612013000100019. PMid:24252955. 